\title{
Evolutionary history of a vanishing radiation: isolation-dependent persistence and diversification in Pacific Island partulid tree snails
}

Taehwan Lee', Jingchun Li ${ }^{1}$, Celia KC Churchill ${ }^{2}$ and Diarmaid Ó Foighil ${ }^{1 *}$

\begin{abstract}
Background: Partulid tree snails are endemic to Pacific high islands and have experienced extraordinary rates of extinction in recent decades. Although they collectively range across a 10,000 km swath of Oceania, half of the family's total species diversity is endemic to a single Eastern Pacific hot spot archipelago (the Society Islands) and all three partulid genera display highly distinctive distributions. Our goal was to investigate broad scale (range wide) and fine scale (within-Society Islands) molecular phylogenetic relationships of the two widespread genera, Partula and Samoana. What can such data tell us regarding the genesis of such divergent generic distribution patterns, and nominal species diversity levels across Oceania?

Results: Museum, captive (zoo) and contemporary field specimens enabled us to genotype 54 of the $\sim 120$ recognized species, including many extinct or extirpated taxa, from 14 archipelagoes. The genera Partula and Samoana are products of very distinct diversification processes. Originating at the western edge of the familial range, the derived genus Samoana is a relatively recent arrival in the far eastern archipelagoes (Society, Austral, Marquesas) where it exhibits a stepping-stone phylogenetic pattern and has proven adept at both intra-and inter- archipelago colonization. The pronounced east-west geographic disjunction exhibited by the genus Partula stems from a much older long-distance dispersal event and its high taxonomic diversity in the Society Islands is a product of a long history of within-archipelago diversification.

Conclusions: The central importance of isolation for partulid lineage persistence and diversification is evident in time-calibrated phylogenetic trees that show that remote archipelagoes least impacted by continental biotas bear the oldest clades and/or the most speciose radiations. In contemporary Oceania, that isolation is being progressively undermined and these tree snails are now directly exposed to introduced continental predators throughout the family's range. Persistence of partulids in the wild will require proactive exclusion of alien predators in at least some designated refuge islands.
\end{abstract}

Keywords: Oceania, Land snail, Phylogeny, Dispersal, Extinction, Endemism, Conservation

\section{Background}

The Pacific Ocean comprises a third of the Earth's surface and contains approximately 25,000 oceanic islands [1]. Most are clustered within hot spot and island arc volcanic archipelagoes scattered across Oceania, a tropical region extending from New Guinea to Hawaii and Easter Island [2]. These islands represent highly distinctive evolutionary settings for terrestrial biotas: they have never been

\footnotetext{
* Correspondence: diarmaid@umich.edu

${ }^{1}$ Museum of Zoology and Department of Ecology and Evolutionary Biology, University of Michigan, 1109 Geddes Avenue, Ann Arbor, Ml 48109-1079, USA Full list of author information is available at the end of the article
}

connected to continental landmasses and trans-oceanic founder speciation, followed by varying degrees of in situ cladogenesis, is the primary diversification process [3-6].

Oceanic island biotas start out with a depauperate and disharmonic composition, i.e., suites of taxa that are prevalent in continental ecosystems, but incapable of dispersing across oceanic barriers, are missing [7]. This facilitates the survival of relict lineages and the evolution of endemic adaptive radiations $[3,8,9]$, resulting in a "diversity and stability paradox" [10]: oceanic island biotas are often species poor, but have high endemism; they appear stable (pending maintenance of biotic isolation), but are 
susceptible to collapse following anthropogenic disturbance. Indeed, anthropogenic habitat modification/disturbance and human-introduced continental species are the primary drivers of oceanic island extinctions [11]. The small ranges/populations of oceanic island endemics, together with their relative lack of defensive or competitive abilities, render them exceptionally vulnerable to introduced aliens [3,9,12-14].

Although individual islands are often species poor, the cumulative effect of the "diversity and stability paradox" [10] is of global significance: most historical extinctions of birds [15], plants [16] and mollusks [17] worldwide have involved oceanic island endemics. Of particular concern in recent decades has been a major wave of Pacific Island land snail extinctions originating in a misguided biological control program that deliberately introduced a number of alien carnivorous land snails, most notably Euglandina rosea, across much of Oceania [18-21]. It is estimated that E. rosea alone has probably caused the extinction of 134 Pacific Island land snail endemics [17] and among the hardest impacted are members of the family Partulidae [22-26], the subject of this study.

Partulid snails are endemic to the high islands of Oceania i.e. islands with sufficient elevation to generate their own precipitation and support rain forest formation.
They have attained a spectacular 10,000 km-wide collective range from Palau and the Marianas in the northwest to the Marquesas, Austral and Society Islands in the southeast [23; see Figure 1]. Apart from a single Papua New Guinean record of anthropogenic origin $[27,28]$, they are unknown from adjacent continental habitats, a distribution pattern that strongly implicates biotic factors in setting their distributional limits [3]. Partulid inter-island/archipelago dispersal mechanisms are poorly understood but aerial transport (via birds and/or storms) may be more likely than rafting [29-31]. Such chance dispersal events are presumably very rare: most species are endemic to single islands $[3,32,33]$ and the only known partulids with multi-archipelago distributions represent prehistoric anthropogenic introductions [28,34]. Approximately 120 partulid species are currently recognized and half of this nominal diversity is endemic to a single hot spot archipelago, the Society Islands, at the eastern edge of the family's range (Figure 1). In recent decades, Partulidae have experienced catastrophic extinction, centered on the Society Islands, where most of the archipelago's 61 endemic species have been extirpated by Euglandina rosea $[22,23,26,35]$.

Evolutionary studies of oceanic island lineages share common goals such as the identification of continental sister taxa and the inference of the number, timing and

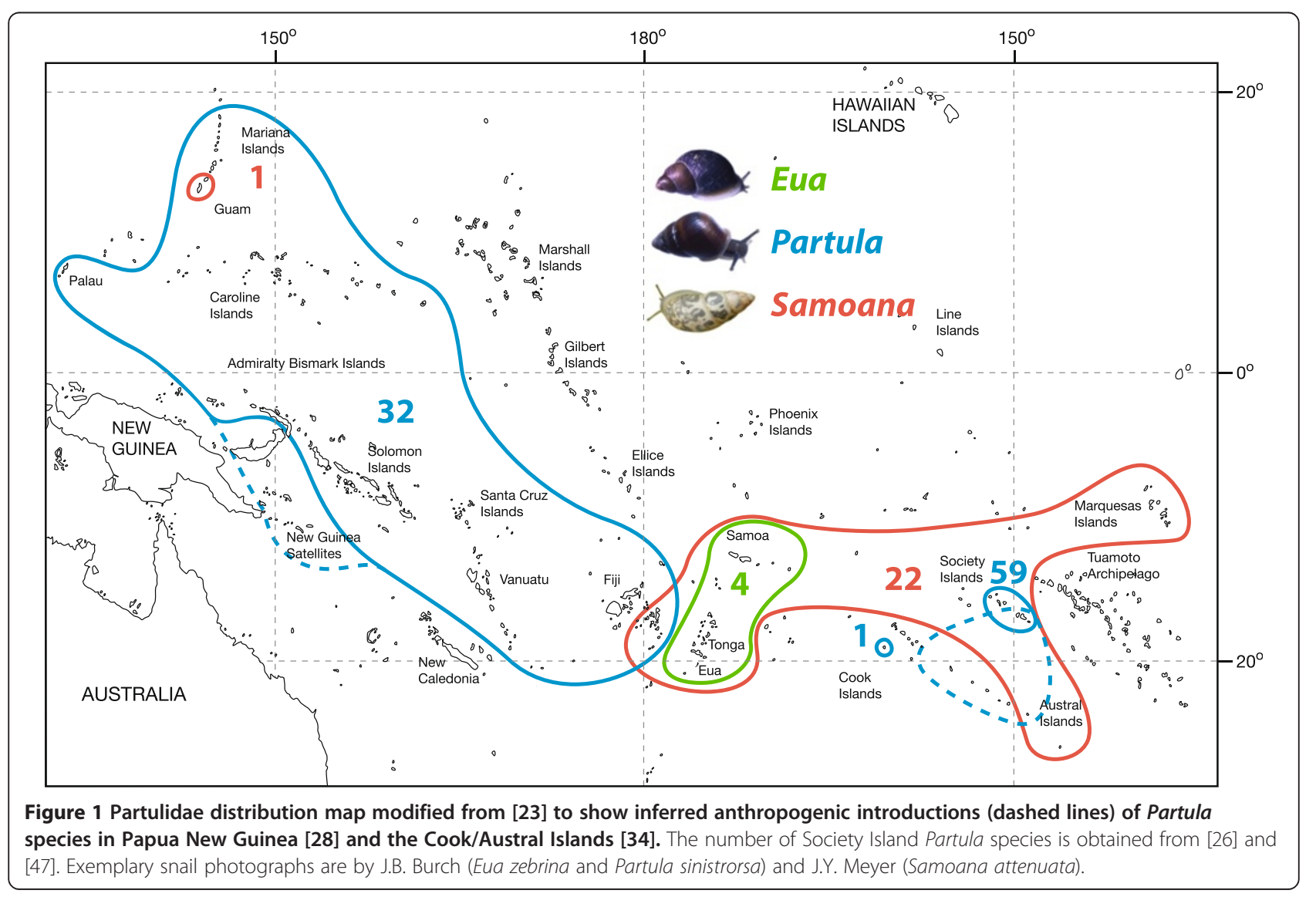


directionality of colonization events among archipelagoes and islands [36]. Unlike Galapagos finches [37] and Hawaiian silverswords [38], for instance, a convincing sister group to Partulidae has not yet been identified [39]; the poorly-studied New Caledonia endemic family Draparnaudiidae (6 known species) is considered the likeliest candidate [40,41]. All available data suggest that Partulidae have had a long evolutionary history in Oceania, dispersing to new islands as older ones sink below sea level. Pilsbry and Cooke [42] partitioned Partulidae into 3 genera (Partula, Samoana and Eua), based primarily on male genital characters, and these have been substantially corroborated by independent molecular character sets $[35,39,43-45]$, with the exception of one Tahitian species complex with highly variable genitalia [46].

Eua has the simplest genital anatomy, contains 4 species, and is restricted to the central part of the family's range: 1 species on 'Eua (Tonga), 3 in the Samoan Archipelago (Figure 1). Samoana contains approximately 23 species and has a disjunct distribution: extensively distributed throughout central and eastern archipelagoes but with a solitary western species, S. fragilis, in the Mariana Islands $5000 \mathrm{~km}$ from its nearest congener in Fiji (Figure 1). Partula, the most speciose genus ( $\sim 92$ species), exhibits a strikingly different disjunct pattern: widespread in western archipelagoes, absent from the central part of the family's range and, excluding anthropogenic populations [34], restricted to a small subset of eastern islands: 1 species in Rarotonga (Cook Islands), and a remarkable 59 species $[26,33,47]$ in a single hot spot archipelago, the Society Islands (Figure 1).

Kondo and Burch [48] implicitly proposed the following phylogenetic pattern of generic relationships: (Eua (Samoana, Partula)), a topology that has been corroborated by available molecular phylogenies. Land snail gene trees that have included all three genera [39] have placed Eua basally, a topology that positions the last common ancestor of extant Partulidae in the central part of the present-day partulid range. Partulid phylogenies rooted with Eua species [35,44,45] have consistently recovered reciprocally monophyletic Samoana and Partula genera. Goodacre and Wade's [44] nuclear ribosomal phylogeny supported an eastward expansion of Samoana species from Samoa to the Society and Marquesan archipelagoes, but the Partula clade had a pronounced basal polytomy and yielded little historical insight into this genus's disjunct distribution.

A comprehensive understanding of partulid diversification processes requires not only a range-wide perspective, but also the development of finer scale within-archipelago and within-island phylogenies. This has been best developed for the Society Island radiation where a number of workers have proposed a "progression rule" model of evolution - lineages sequentially colonize newer islands within an archipelago as they are formed [4] - for the well-studied Partula species of Moorea and Tahiti [43,46,49-53]. In this model, neighboring older islands (Leeward group) seeded the younger islands (Windward group), first Moorea, then Tahiti, via single colonization events and subsequent speciation occurred in situ within each island [43,46,49-53]. This model does not apply to the four endemic Society Island Samoana species, two of which have multi-island distributions $[35,54,55]$.

The goal of our study was to build on Goodacre's pioneering molecular phylogenetic work $[44,51,55]$ by constructing higher-resolution broad scale (range wide) and fine scale (within-Society Island archipelago) partulid phylogenetic relationships for nuclear and mitochondrial genetic markers. Although our geographically- and taxonomicallyenhanced sampling scheme was far from exhaustive, and heavily weighted toward Moorean and Tahitian taxa (Table 1), the incorporation of museum and captive (zoo) samples allowed us to genotype numerous extinct and extirpated taxa that span the family's range; the Solomon Islands being the only major archipelago that lacked a representative. It included all 4 species of Eua from 4 islands and 2 archipelagoes, 13 species of Samoana from 13 islands and 5 archipelagoes, as well as 37 species of Partula sampled from 31 islands and 11 archipelagoes (Table 2). We were particularly interested in investigating the intergeneric relationships and disjunct distributions of Samoana and Partula $[23,33,48]$ : what is the genesis of such divergent generic distribution patterns, and nominal species diversity levels, in the Western and Eastern segments of the family's range (Figure 1)?

Table 1 Summary data for partulid taxa genotyped for this study showing the fraction of species in each genus sampled, the number of islands and archipelagoes they were sourced from and the intensive sampling of Tahitian and Moorean Partula populations

\begin{tabular}{lllll}
\hline & Species sampled (species described) & Archipelagos represented & Islands represented & Individuals genotyped \\
\hline Eua & $4(4)$ & 2 & 4 & 6 \\
Samoana & $14(25)$ & 5 & 13 & 51 \\
Partula & $37(99)$ & 11 & 29 & 624 \\
Tahitian Partula & $7(8)$ & & 1 & 270 \\
Moorean Partula & $7(7)$ & 14 & 1 & 140 \\
Total & $55(128)$ & 41 & 681 \\
\hline
\end{tabular}


Table 2 Taxonomic designations, sampling locations, IUCN Red List Status and sources for the $\mathbf{5 4}$ partulid species genotyped in this study

\begin{tabular}{ll}
\hline Taxonomy & Island, Archipelago \\
\hline Eua globosa Pilsbry \& Cooke, 1934 & 'Eua, Tonga \\
E. expansa (Pease, 1872) & Savai'i, Samoa \\
E. montana (Cooke \& Crampton, 1930) & Upolu, Samoa, \\
E. zebrina (Gould, 1847) & Tutuila, Samoa (Am.) \\
Samoana fragilis (Ferussac, 1821) & Guam, Marianas \\
S. abbreviata (Mousson, 1869) & Tutuila, Am. Samoa \\
S. conica (Gould, 1847) & Tutuila, Am. Samoa \\
S. thurstoni (Cooke \& Crampton, 1930) & Ofu, Am. Samoa \\
S. canalis (Mousson, 1865) & Savai'i, Samoa \\
S. stevensoniana (Pilsbry, 1909) & Savai'i, Samoa \\
S. margaritae (Crampton \& Cooke, 1953) & Rapa, Australs \\
S. oreas (Crampton \& Cooke, 1953) & Raivavae, Australs \\
S. attenuata (Pease, 1864) & Raiatea/Moorea/Tahiti, Society
\end{tabular}

S. burchi Kondo, 1973

S. diaphana Crampton \& Cooke, 1953

S. bellula (Hartman, 1885)

S. decussatula (Pfeiffer, 1850)

S. strigata (Pease, 1868)

Partula calypso Semper, 1865

P. thetis Semper, 1865

P. gibba Ferussac, 1821

P. radiolata Pfeiffer, 1846

P. emersoni Pilsbry, 1913

P. carteriensis (Quoy \& Gaimard, 1832)

P. similaris Hartman, 1886
P. auraniana Hartman, 1888

P. turneri Pfeiffer, 1860

P. lirata Mousson, 1865

P. subgonochila Mousson, 1871

P. assimilis Pease, 1868
Tahiti, Society

Moorea/Tahiti, Society

Ua Pou, Marquesas

Tahuata/Hiva Oa, Marquesas

Nuku Hiva, Marquesas

Babeldaob, Palau

Ulong /Babeldaob/Ngeruktabel, Palau

Guam/Saipan, Marianas

Guam, Marianas

Pohnpei, Carolines

New Britain, Bismarcks

Woodlark/Boiaboiawaga/Goodenough, d'Entrecasteaux

Toga/Tegua/Loh/Metoma/Hiu,Torres, Vanuatu

Erromanga/Tanna, Vanuatu

Thikombia-i-lau, Fiji

Alofi, Wallis \& Futuna

Rarotonga, Cooks

\section{IUCN Red}

list status

Critically Endangered

Unevaluated

Unevaluated

Endangered

Critically Endangered

Critically Endangered

Unevaluated

Endangered

Endangered

Unevaluated

Vulnerable

Critically Endangered

Critically Endangered

Critically Endangered
Endangered
Critically Endangered
Critically Endangered

Holland/2004

Coote/2005

Critically Endangered Holland/2004

Critically Endangered

Endangered

Critically Endangered

$\mathrm{FMNH} / 2005$

FMNH/1995, 1998, 2006

$\mathrm{FMNH} / 1958$

UMMZ/1970

ZSL/1970

Critically Endangered FMNH/1995

ZSL/1995

Critically Endangered Holland/2011

Data Deficient FLMNH/2005

Data Deficient UMMZ/1966

FMNH/2002

FLMNH/2003

Endangered

Fontaine/2009

Unevaluated

FMNH/1972

FLMNH/1984

Unevaluated ZSL/1999

Critically Endangered ZSL/2007

Unevaluated Coote/2004 
Table 2 Taxonomic designations, sampling locations, IUCN Red List Status and sources for the $\mathbf{5 4}$ partulid species genotyped in this study (Continued)

P. lutea Lesson, 1831
P. dentifera Pfeiffer, 1853
P. faba (Gmelin, 1791)
P. hebe (Pfeiffer, 1846)
P. labrusca Crampton \& Cooke, 1953
P. meyeri Burch, 2007
P. tristis Crampton \& Cooke, 1953
P. turgida (Pease, 1865)
P. arguta (Pease, 1865)
P. rosea Broderip, 1832
P. varia Broderip, 1832
P. aurantia Crampton, 1932
P. exigua Crampton, 1917
P. mirabilis Crampton, 1924
P. mooreana Hartman, 1880
P. suturalis Pfeiffer, 1855
P. taeniata (Mörch, 1850)

P. taeniata (Mörch, 1850)

P. tohiveana Crampton, 1924

P. affinis Pease, 1867

P. clara Pease, 1864

P. filosa Pfeiffer, 1853

P. hyalina Broderip, 1832

P. nodosa Pfeiffer, 1851

\section{Bora Bora, Society}

Raiatea, Society

Raiatea, Society

Raiatea, Society

Raiatea, Society

Raiatea, Society

Raiatea, Society

Raiatea, Society

Huahine, Society

Huahine, Society

Huahine, Society

Moorea, Society

Moorea, Society

Moorea, Society

Moorea, Society

Moorea, Society

Moorea, Society

Moorea, Society

Tahiti, Society

Tahiti, Society

Tahiti, Society

Tahiti, Society

Mangaia/ Mauke, Cooks

Rimatara/Rurutu/Tubuai/Raiavavae, Australs

Tahiti, Society

\begin{tabular}{|c|c|}
\hline Extinct & UMMZ/1970 \\
\hline \multirow[t]{2}{*}{ Extinct in the Wild } & UMMZ/1970 \\
\hline & ZSL/1991 \\
\hline \multirow[t]{2}{*}{ Extinct in the Wild } & UMMZ/1970 \\
\hline & ZSL/1991-2 \\
\hline \multirow[t]{2}{*}{ Extinct in the Wild } & UMMZ/1970 \\
\hline & ZSL/1991 \\
\hline Extinct & ZSL/1992 \\
\hline Critically Endangered & Meyer/2006 \\
\hline Extinct in the Wild & ZSL/1991 \\
\hline Extinct & ZSL/1991 \\
\hline Extinct & ZSL/1991 \\
\hline Extinct in the Wild & ZSL/1987 \\
\hline Extinct in the Wild & ZSL/1991, 1994 \\
\hline Extinct & UMMZ/1970 \\
\hline Extinct & UMMZ/1970 \\
\hline \multirow[t]{2}{*}{ Extinct in the Wild } & UMMZ/1970 \\
\hline & ZSL/1984-5 \\
\hline \multirow[t]{2}{*}{ Extinct in the Wild } & UMMZ/1970 \\
\hline & ZSL/1982, 1985 \\
\hline \multirow[t]{2}{*}{ Extinct in the Wild } & UMMZ/1970 \\
\hline & ZSL/1980-6 \\
\hline \multirow[t]{5}{*}{ Critically Endangered } & UMMZ/1970 \\
\hline & ZSL/1981-6 \\
\hline & Coote/2005-7 \\
\hline & Hickman/2006 \\
\hline & Meyer/2006 \\
\hline Extinct in the Wild & ZSL/1982 \\
\hline \multirow[t]{2}{*}{ Critically Endangered } & UMMZ/1970 \\
\hline & ZSL/1995 \\
\hline \multirow[t]{3}{*}{ Critically Endangered } & UMMZ/1970 \\
\hline & ZSL/1995, 1997 \\
\hline & Coote/2004-7 \\
\hline Extinct & UMMZ/1970 \\
\hline \multirow[t]{5}{*}{ Vulnerable } & UMMZ/1970 \\
\hline & ZSL/1996 \\
\hline & Coote/2004-7 \\
\hline & Fontaine \& Gargominy/2002-4 \\
\hline & McCormack/2006 \\
\hline Extinct in the Wild & UMMZ/1970ZSL/1984 \\
\hline
\end{tabular}


Table 2 Taxonomic designations, sampling locations, IUCN Red List Status and sources for the $\mathbf{5 4}$ partulid species genotyped in this study (Continued)

\begin{tabular}{|c|c|c|c|}
\hline \multirow[t]{3}{*}{ P. otaheitana (Brugière, 1789) } & Tahiti, Society & Critically Endangered & UMMZ/1970 \\
\hline & & & ZSL/1995 \\
\hline & & & Coote/2005-7 \\
\hline P. producta Pease, 1865 & Tahiti, Society & Extinct & UMMZ/1970 \\
\hline
\end{tabular}

See Additional file 3: Table S1 for detailed information, including museum voucher and GenBank numbers, on the genotyped snails.

\section{Results \& discussion}

\section{Intergeneric relationships}

Previous partulid molecular phylogenies [35,39,43-45] have either ignored or under-sampled Western Pacific taxa, the most comprehensive representation being 4 western species of Partula [44]. We were able to incorporate 14 Western Pacific species (Table 2) in our analyses, including for the first time Samoana fragilis, the sole western member of that genus, and 2 of the 3 endemic Partula species in Palau, the westernmost archipelago of the family's range (Figure 1). Twelve of the Western Pacific partulids clustered as expected with Central/Eastern Pacific congeners in our molecular phylogenetic trees. However, the two Palauan species, $P$. thetis and $P$. calypso, were topologically distinct from all of their congeners, forming discrete and robustly supported clades with Samoana species. For our relatively conserved marker, the large nuclear ribosomal gene fragment, the two Palauan Partula species formed a shallow polytomy with Samoana fragilis, within a polytomous Samoana clade (Figure 2). The faster-evolving $\mathrm{mt}$ COI marker yielded a more fully resolved inference of Palauan partulid genealogical relationships - see Figure 3 for the salient segment of this much larger phylogenetic tree (the complete topology is available in Additional file 1 : Figure S1). Here, $P$. thetis and $P$. calypso were sister to all genotyped Samoana species.

The unexpected phylogenetic placement of the two Palauan Partula taxa with Samoana species raises a question concerning their generic status. Pilsbry and Cooke [42] distinguished the genera Partula and Samoana primarily on male genital characters: the latter being differentiated into distinct epiphallus and penis segments connected by an extension of the penial retractor muscle that is absent in other partulids. Kondo's Ph.D. thesis [56] contains detailed diagrams of the reproductive tracts of the three endemic Palauan species (P. thetis, P. calypso and P. leucothoe, the latter was unavailable for this study) and all three unambiguously displayed the male genital anatomy characteristic of the genus Partula. These anatomical data, together with the robust, well-resolved $\mathrm{mt}$ gene tree topology (Figure 3) demonstrate that the genus Partula is paraphyletic and that the distinct genital anatomy of Samoana species is derived. In contrast to Kondo and Burch's [48] hypothesis of intergeneric relationships (Eua (Samoana, Partula)) - our data are consistent with
(Eua (Partula1 (Partula2, Samoana))) where Partula1 represents all non-Paluan members of the genus and Partula2 represents the two genotyped Palauan species.

\section{West-east dispersal of Samoana}

The most remarkable feature of the distribution of Samoana is the presence of a single isolated species, $S$. fragilis, bearing the characteristic Samoana genital anatomy [56], in the Western Pacific (Figure 1). Genotyping S. fragilis museum specimens sampled in 1945 allowed us to put this geographic disjunction into a phylogenetic context for the first time. Our two molecular markers yielded very different levels of phylogenetic resolution. The more conserved nuclear large ribosomal gene fragment produced a shallow clade with a basal polytomy such that interrelationships among Western (including the two Palauan Partula species) and Eastern Samoana taxa were unresolved (Figure 2). The mt marker provided much better resolution (Figure 3) and we base our discussion of the evolutionary history of Samoana on this topology. It shows that the Samoana clade is anchored in the West by its exclusive sister relationship with Palauan Partula species and by the placement of the Marianas species S. fragilis at its base the sole western species is not a derived founder lineage (Figure 3). This is a somewhat surprising result because it places the inferred evolutionary origins of the genus not in the Eastern Pacific, home to 21/22 Samoana species (Figure 1), but instead in the far western portion of the partulid range (Figure 3).

The mt gene tree topology (Figure 3) is consistent with a western origin of the genus Samoana followed by progressive eastward colonization of derived lineages. S. fragilis is sister to the Samoan congener S. thurstoni, although the posterior probability value for this node is low. A derived clade, that approximates a stepping-stone dispersal pattern from West to East, is evident for the easternmost archipelagoes with Samoa as the regional source. Three closely-related Samoan species - S. conica, S. stevensonia and S. abbreviata - are robustly sister to derived congers in the Society, Austral and Marquesan archipelagoes, the latter two forming monophyletic clades. Reconstructing the multi-archipelagic dispersal pathways of these Eastern lineages is complicated by a basal polytomy involving Austral taxa and two Society Island lineages (Figure 3). However, the sister status of 


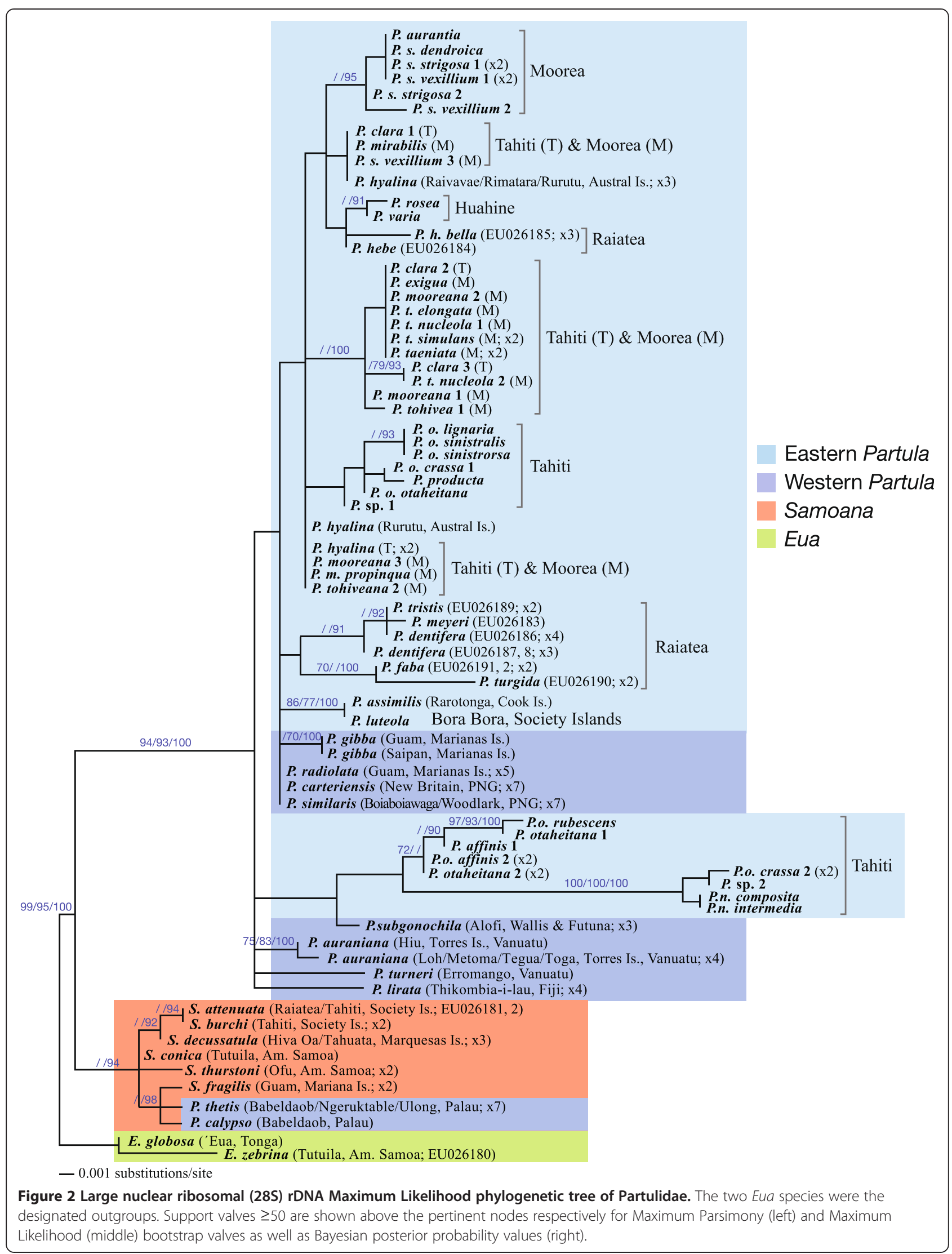




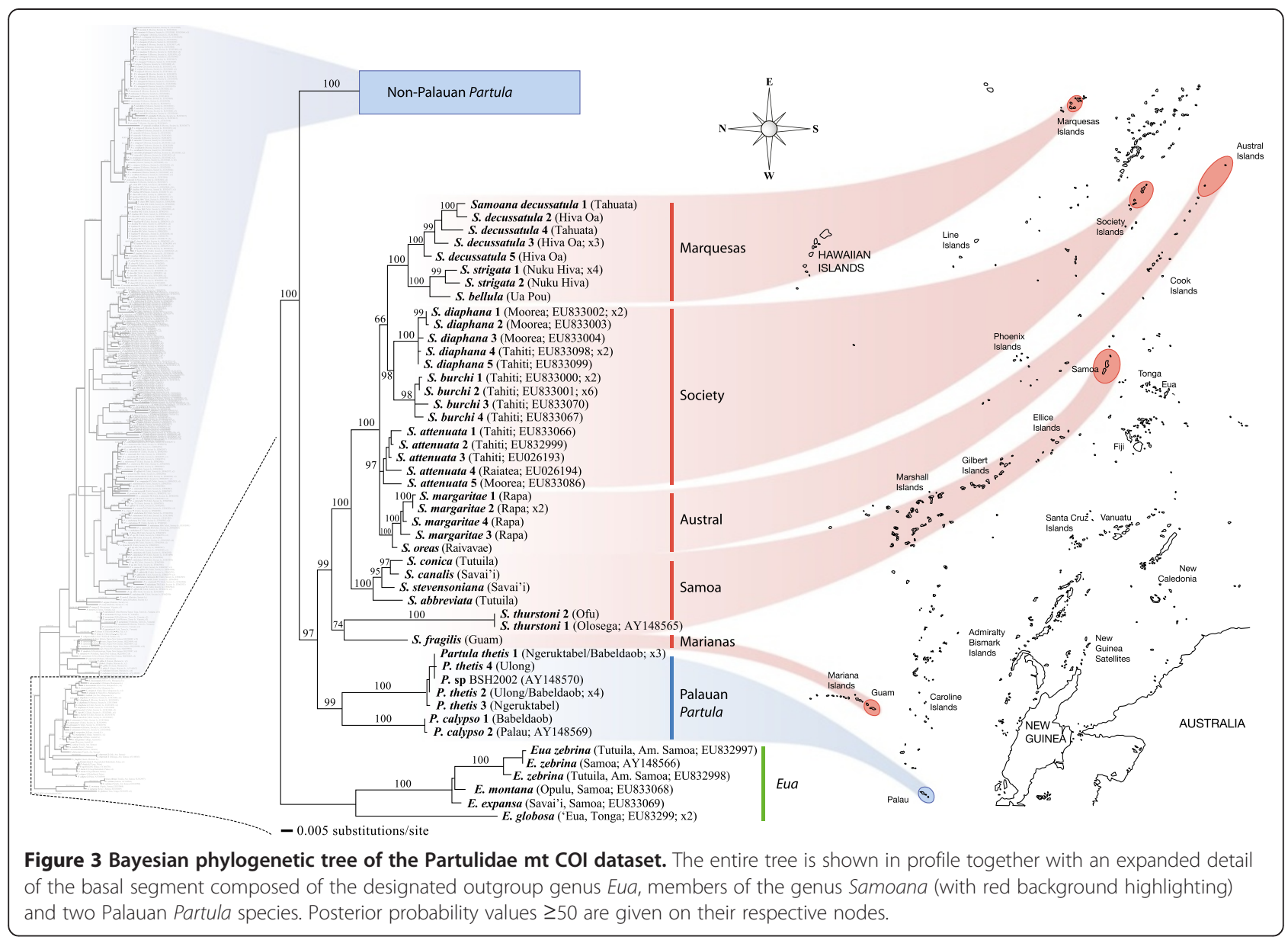

the Marquesan taxa with two Society Island congeners, S. diaphana and S. burchi, is consistent with an earlier inference [44] of dispersal and colonization among these two archipelagoes. Our results corroborate a previous allozyme study [57] regarding Marquesan monophyly and adaptive radiation - Marquesan taxa exhibit a diversity of distinct shell phenotypes. Interestingly, so do the two Society island montane forest sister taxa: the thinshelled S. diaphana (Moorea and Thaiti) and the thickshelled Tahitian endemic S. burchi [54].

Although our data provide new insights into the evolution and biogeography of the genus Samoana, they raise obvious follow-on questions: if the genus originated in the West, why does almost all the extant diversity occur in Eastern archipelagoes and why are Samoana species missing from a huge swathe of the family's range from the Marianas to Fiji (Figure 1)? We consider it unlikely that the genus extended its range across this $\sim 5000 \mathrm{~km}$ gap in a single dispersal event and hypothesize that at least some intermediate archipelagoes such as the Caroline Islands, Bismarck Archipelago, Solomon Islands, Santa Cruz Islands and Vanuatu may have supported populations at some time in the past. Present day absence of the genus Samoana from at least some of these archipelagoes is probably not due to a lack of dispersal ability. Our data indicate that a Samoan lineage was capable of stepping-stone colonization of Eastern archipelagoes up to $3000 \mathrm{~km}$ distant, a range that ostensibly puts the Western archipelagoes of Vanuatu, Santa Cruz and the Solomon Islands within equivalent reach. The absence of the genus Samoana from much of the Western range of the family may stem from (as yet unidentified) ecological factors that have driven original populations to extinction and prevented rare long-distant migrants from reestablishing new populations.

\section{West-east Partula disjunction - product of a single dispersal event}

The $\sim 2000 \mathrm{~km}$ geographic disjunction - from the Lau Islands of Fiji to Rarotonga in the Cook Islands - separating Western and Eastern members of the genus Partula (Figure 1) has yet to be put into a comprehensive phylogenetic framework. Although our sampling of the genus Partula is heavily weighted toward Eastern populations, we have genotyped 11 species from across the Western range (Marianas, Palau, Carolines, Bismarck Archipelago 
and the Massim Region of Papua New Guinea, Vanuatu, Wallis and Futuna, Fiji). This broad sampling allows some confidence that we have captured much of the regional phylogenetic framework, if not all of its detail. Similarly, for the Eastern Partula species, our taxon sampling is geographically comprehensive: the 26 species genotyped include the sole non-anthropogenic Cook Island species, $P$. assimilis, as well as representatives from the all of the salient Society Islands except for Tahaa, which shares the same lagoon as Raiatea.

Our phylogenetic analyses of the large nuclear gene fragment consistently produced a very poorly resolved topology for the non-Palauan Partula species, as previously reported [44], e.g., Figure 2 contains two polytomies, each with a mix of Western and Eastern species. We are therefore basing our inferences of West-east Partula relationships on the mt topology. As shown in Figure 4, the Western taxa place at the base of the nonPalauan Partula clade separated by a robust $(\mathrm{PPS}=100)$ node from all Eastern congeners. This is consistent with a single dispersal event from West to East (Figure 1).

Phylogenetic relationships among the non-Palauan Western Partula taxa were obscured by a basal polytomy (Figure 4). Within-archipelago monophyly was evident only for Marianas taxa and these were weakly sister to the Micronesian P. emersoni. The phylogenetic affinities of Papua New Guinean populations of $P$. carteriensis and P. similaris, flagged as likely anthropogenic introductions [28], remained uncertain. The two easternmost taxa had distinct topological placements: $P$. subgonochila (Wallis \& Futuna) was a member of the basal polytomy whereas the Fijian P. lirata was sister to one of the Vanuatu species, $P$. auraniana (Torres Islands). These disparate results imply that a more comprehensive sampling of Western taxa is required to capture a high-resolution understanding of regional evolutionary history. Unfortunately, this will have to be accomplished quickly given the ongoing decline and extirpation of many Western Pacific partulid populations and species [24,58-61].

\section{Eastern Partula diversification}

Figure 5 shows, in outline form, the mt tree topology of the Eastern Partula clade labeled by source island - a fullsized topology containing details of individual genotype identification is available in Additional file 1: Figure S1. Apart from major gaps for the islands Tahaa ( $0 / 6$ species) and Raiatea (7/34 species), sampling of the Society Islands endemic Partula radiation was almost complete: Bora Bora (1/1), Huahine (3/3), Moorea (7/7) and Tahiti (7/8 the missing species, $P$. cythera, has not been seen since its

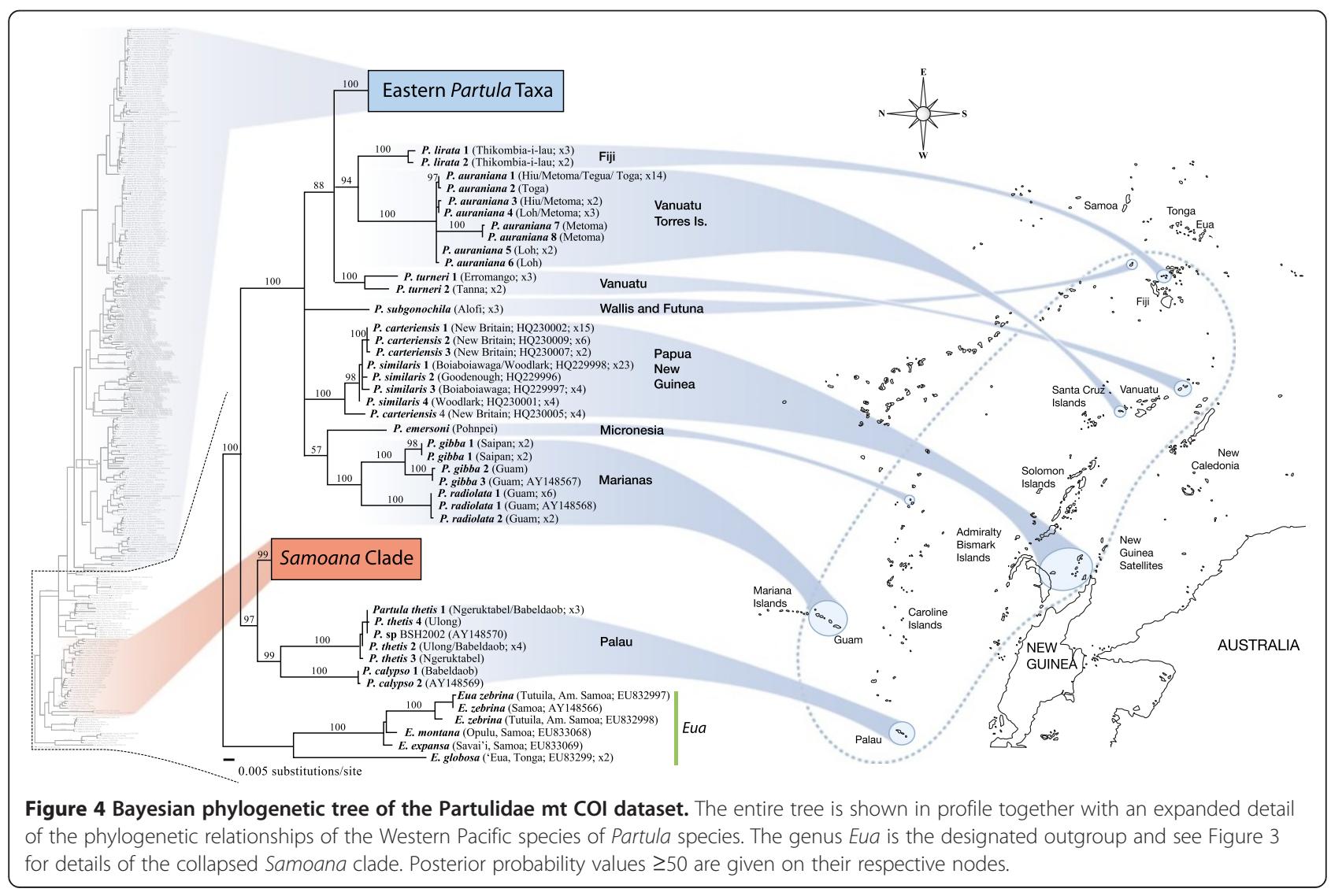




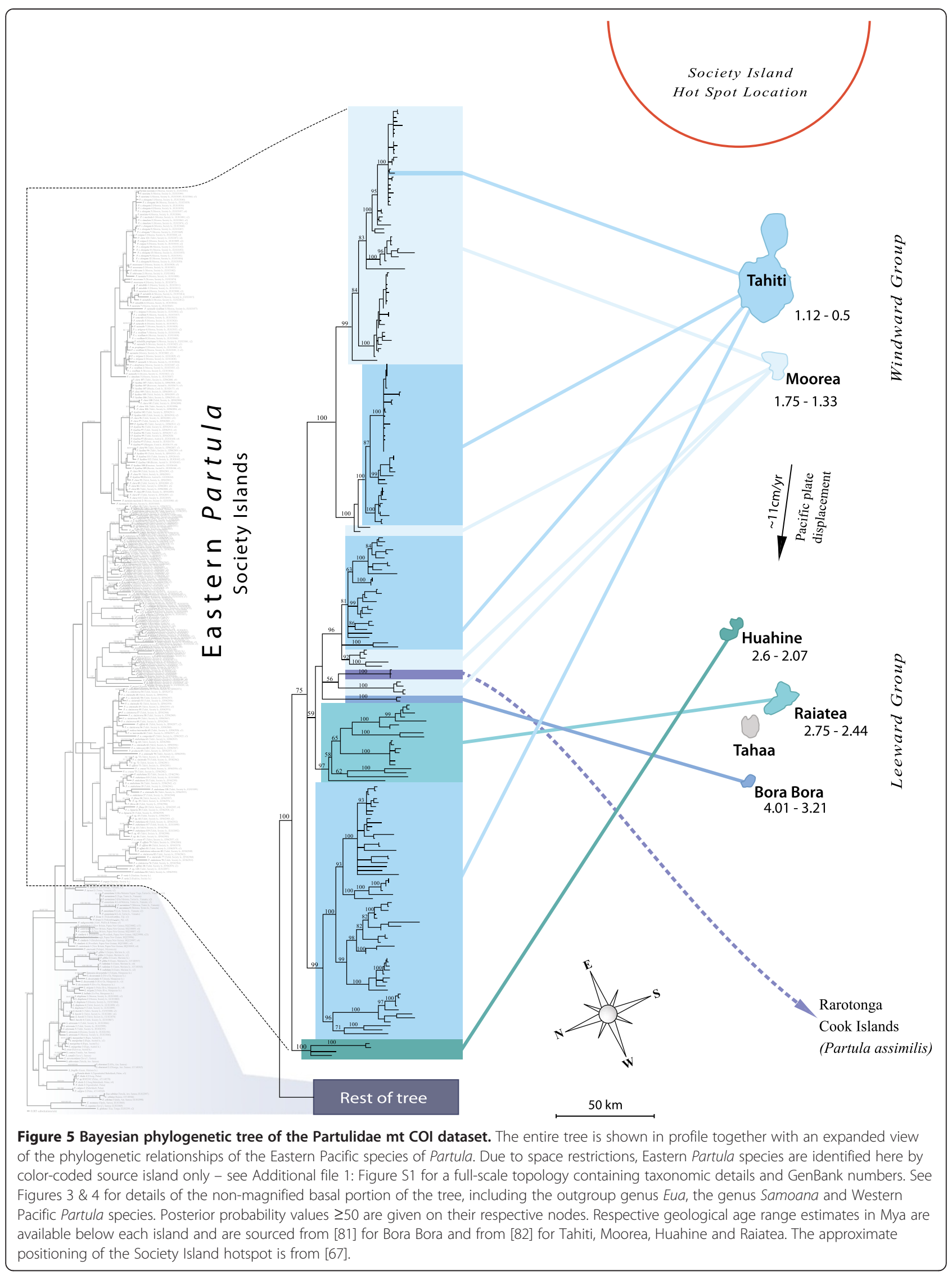


discovery on a remote interior mountain slope in the 1920's [62]).

The only Eastern Partula species not endemic to the Society Islands $-P$. assimilis of Rarotonga (Cook Islands) - is positioned within the Society Island clade (Figure 5), weakly sister to a minor, divergent Moorean P. suturalis clade and to the Bora Bora endemic P. lutea, with which it shares a large nuclear ribosomal genotype (Figure 2) as well as allozymic affinities [43]. We agree with Johnson et al. [43] that $P$. assimilis probably represents a founder lineage from a Society Islands source; the only know Partula transplant from that hotspot archipelago apart from anthropogenic populations of the Tahitian endemic P. hyalina [34].

Concerning the Society Islands topology, a number of important stem nodes within the clade were poorly supported and, consistent with parallel studies on this archipelago's biota [53], there was little agreement with progression rule [4] expectations for the archipelago, i.e., topological congruence with the chronological sequence of island formation. Only one (Huahine) of three older Society Islands represented in the topology (Bora Bora, Raiatea, Huahine; all members of the Leeward Island subgroup) positioned basally. The oldest Society Islands with partulids, Bora Bora and Raiatea, placed in derived positions, weakly sister to a heterogeneous assemblage that included the Rarotonga species, two Moorean clades and one Tahitian clade (Figure 5).

One consistent topological difference between the Leeward and Windward Island lineages concerned their degree of within-island monophyly. Genotyped snails from each Leeward Island formed well-supported (PPS $\geq 97$ ) single island-specific clades. Snails from each Windward Island formed four discrete lineages, three of which had exclusive phylogenetic relationships (PPS 296) with snails in the other Windward island, as described in detail in an earlier study [35]. However, the phylogenetic affinities of the largest and most deeply branched of the four Tahitian mt clades remained enigmatic. This robust (PPS $=99)$ Tahitian clade positioned on a basal polytomy that encompassed both Leeward and Windward Island lineages and it lacked an identifiable sister lineage, either on Moorea, or on any of the other Society Islands (Figure 5).

The Figure 5 topology is incompatible with the prevailing speciation model for Moorean and Tahitian Partula that views all congeners on each Windward Island as the product of a single colonization event: a Leeward Island source for Moorea and a single Moorean source for the subsequent colonization of Tahiti [49]. The model has a narrow base of empirical support: allozyme phylogenies from 24 species of Partula that have been weighted on the basis of allele frequency $[43,49]$. These data overturned previous inferences - based on reproductive relationships and morphological similarities - that Tahiti was colonized by multiple Moorean lineages [63]. However, the allozyme data were less than robust: an unweighted (UPGMA) analysis of the same allozyme dataset yielded a substantially distinct topology in which the Tahitian species were no longer monophyletic [43] and a later reanalysis yielded another topology consistent with back-migration from Tahiti to the southern part of Moorea [64]. Salient DNA phylogenies, whether using nuclear ribosomal [44, this study] or $\mathrm{mt}[35,50-52$, this study] markers have failed to recover the model's predicted topology. The mt studies, in particular, have consistently revealed the presence of multiple exclusive sister relationships among subsections of Moorean and Tahitian Partula mt treespace [35, 50-52, this study].

Despite these incongruences, the Windward Island Partula speciation model [49] has remained the consensus conceptual framework for speciation studies of Moorean and Tahitian Partula species: speciation is viewed as having occurred in situ within each island $[43,46,49-53,65]$. Consistent with this view, examples of Moorean/Tahitian mt polyphyly have been interpreted either as being due to convergent molecular evolution (for restriction fragment length polymorphism data $[23,50]$, or to retained ancestral $\mathrm{mt}$ polymorphisms [51-53], rather than being products of inter-island gene flow involving multiple discrete lineages. However, both of these non-gene flow interpretations are problematic. The large majority of $\mathrm{mt}$ COI nucleotide substitutions observed among Moorean and Tahitian taxa are synonymous (data not shown) and are therefore unlikely to stem from selection-driven convergent evolution. The ancestral polymorphism interpretation requires a vicariant model of inter-island genetic differentiation that is inapplicable to Moorea and Tahiti, two spatially discrete islands that have never been joined $[66,67]$.

We propose a new speciation model for Tahitian Partula taxa that involves four discrete founding lineages. Three of the four have explicit phylogenetic ties to Moorean congeners, as detailed earlier [35], but the largest, comprising half of Tahitian mt treespace, is of undetermined provenance (Figure 5). This new model is consistent with parallel Society Island studies that have uncovered a role for multiple independent colonizations in the evolution of Tahiti's endemic biota [53].

\section{Age of the Society Islands Partula radiation}

A standout feature of the biogeography of Partulidae is the markedly asymmetric distribution of alpha diversity across the family's 10,000 km range (Figure 1). Half of the nominal species diversity is endemic to six Society Islands spanning a mere $320 \mathrm{~km}$ of Oceania with a quarter being endemic to a single island: the $167 \mathrm{~km}^{2}$ Raiatea [23]. The extraordinary concentration of 59 species of Partula within this single hotspot archipelago raises questions of taxonomic equivalency 
(species descriptions are typically based on shell phenotype distinctions) and lineage persistence across the range. While we cannot engage meaningfully here with the fraught topic of Partula species designations [52,64,68], we can address the issue of lineage persistence by constructing a time-calibrated phylogeny for our molecular dataset.

Figure 6 shows, in outline form, the time-calibrated Partulidae mt tree obtained with BEAST (see details of the topology in Additional file 2: Figure S2). Three calibration points based on the geological ages of Bora Bora, Raiatea and Tahiti, were used to date nodes supporting the entire Society Island clade, the endemic Raiatean clade and the largest endemic Tahitian clade, respectively. The BEAST topology differed little from that of the Bayesian analyses (Figures 3,4 and 5) except that the non-Palauan Western Partula species now formed a discrete clade, sister to their Eastern congeners (Figure 6). It yielded a greater inferred age for the Society Island Partula radiation, both for the entire archipelago (3.27 Mya), and for the single island of Raiatea (2.71 Mya), than for the much more widespread sister Western Partula clade (2.41 Mya), the genus Eua (2.31 Mya) and the family range-spanning genus Samoana (2.12 Mya), although note

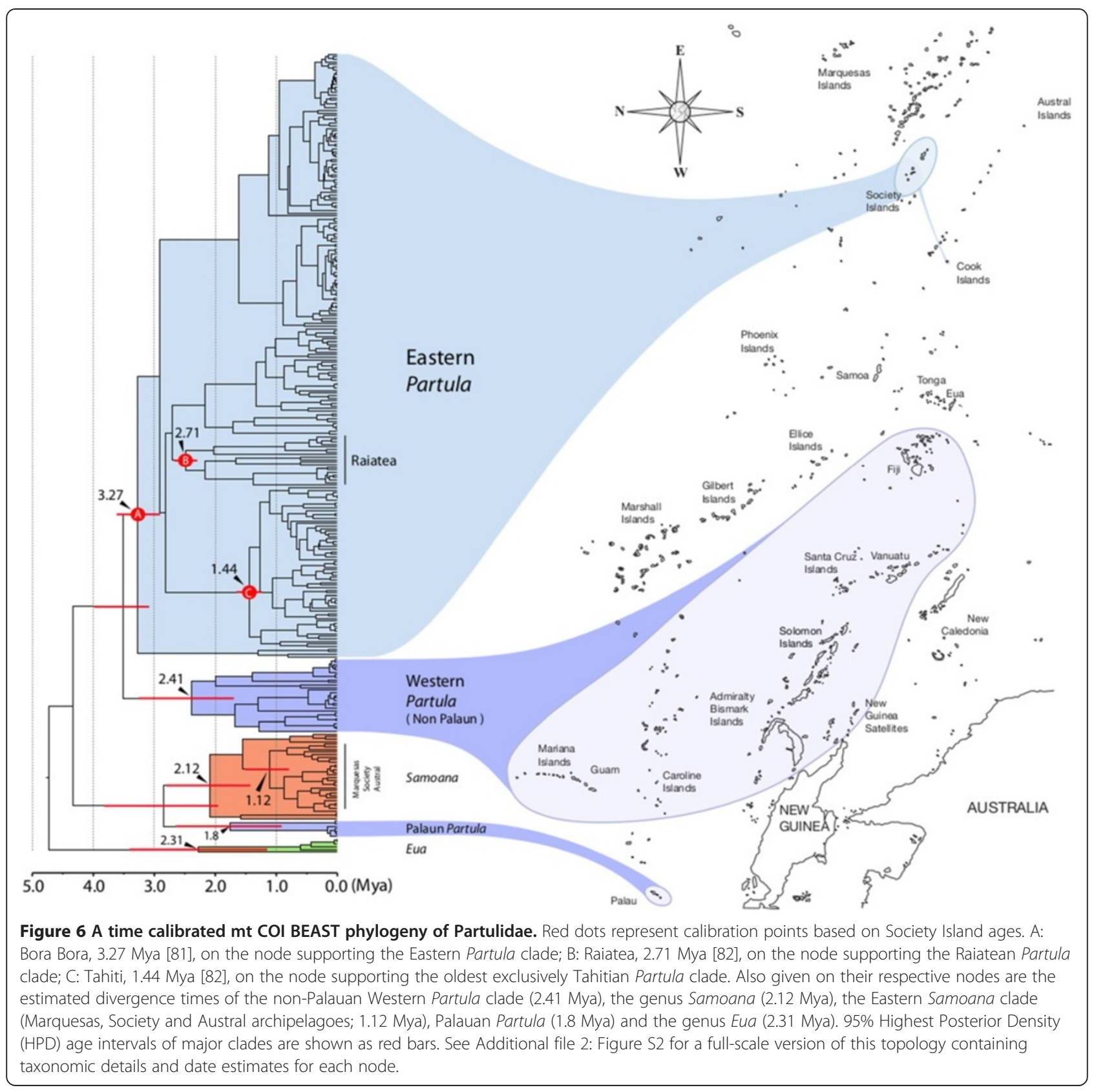


that the 95\% Highest Posterior Density age intervals for many of these nodes overlap (Figure 6).

These time-calibrated data imply that the heightened alpha diversity characteristic of the Society Island Partula radiation, and of the island of Raiatea, resulted at least in part from a longer uninterrupted diversification timeframe than was available elsewhere in the family's range. For this within-archipelago radiation, cladogenesis has apparently unfolded in a qualitatively different manner to that experienced by partulids elsewhere, being characterized (until very recently) by greater lineage longevity coupled with much less lineage dispersal. Within the archipelago, the hyper-speciose Raiatean radiation is correlated with that island's age, area and relief. Despite its relatively advanced age (Figure 5), Raiatea is second only to Tahiti in area and has retained the high island profile (1017 m maximum elevation) required for autonomous rainfall generation and rain forest formation [69,70]. Outside of the Society Island Partula radiation, the small Palauan Partula and Eua clades also show evidence for long-term persistence within modest ranges, but lineage diversification in the Western Partula and Samoana crown clades occurred across much more extensive ranges and necessarily involved multiple episodes of among-archipelago dispersal (Figures 3 and 6).

\section{Divergent histories of Eastern Partula and Samoana radiations}

Although the genera Partula and Samoana overlap in the eastern edge of the family's range, co-occurring in the Society Islands, they appear to have experienced distinct patterns of regional cladogenesis [35]. Partula has many more regional species (59 vs. 15 respectively), but Samoana has a greater eastern range, encompassing the Marquesas and Austral Archipelagoes as well as the Society Islands (Figure 1). They also differ in their regional phylogenetic/population genetic profiles: eastern Samoana species have much lower collective genetic diversity levels and more pronounced phylogenetic cohesiveness $[35,55,57]$. The BEAST topology (Figure 6) yielded new insights into the evolutionary origins of these regional distinctions, showing that the genus Partula established eastern populations much earlier (3.27 Mya) than did Samoana (1.12 Mya). This divergent chronology probably contributed to the regional generic species richness disparity, but not to their distributional disparity. Despite its much longer regional timeframe, the genus Partula has effectively been marooned on the Society Islands, establishing just one interarchipelago founder species in Rarotonga (Cook Islands), excepting anthropogenic introductions of $P$. hyalina [34]. In contrast, the later arriving Eastern Samoana lineage has proven to be a much more effective regional disperser, on both intra-archipelago (many species have multi-island distributions: $33,35,54,55,57$ ] and inter-archipelago scales. Why this should be is unclear, although it may be relevant that many eastern Samoana species produce exceptionally sticky mucus [54,57] and this trait could plausibly increase the likelihood of rare inter-island/archipelago phoretic dispersal events, e.g., on avian vectors.

\section{Conclusions}

Isolation is the primary biological characteristic of oceanic islands [9] and our study, placing partulid species diversity into a range-wide phylogenetic context, underlines the critical importance of biotic isolation in the evolution and diversification of this endemic Pacific island tree snail family. Most partulid species diversity - 59 species of Partula and 15 species of Samoana - is endemic to the Society, Marquesas and Austral archipelagoes. These are the three most isolated archipelagoes in the family's range, being the most remote from Sahul/Asian continental source populations (Figure 1). Prior to human settlement, they experienced the least impact from continental biotas, e.g., they lacked terrestrial mammals (including bats) and reptiles $[71,72]$. This is the rarified biotic setting that supported two very distinct generic radiations unsurpassed elsewhere in the range of Partulidae; that of Partula being the result of prolonged, uninterrupted cladogenesis within a single archipelago, that of Samoana stemming from its ability to disperse and diversify among multiple archipelagoes. Human settlement and modernity/globalization have eroded marine barrier-dependent isolation all across the range of Partulidae, directly exposing these endemic tree snails to an ever growing cast of introduced continental predators. Their continued survival outside of zoos is dependent on our ability to maintain a minimum level of biotic isolation in at least some of the islands of Oceania that could serve as refuges [73] for surviving members of this emblematic Pacific tree snail family.

\section{Methods}

\section{Sampling}

See Table 2 for sampling locations, taxonomic identity and IUCN status of partulid snails genotyped in this study. The vast majority of our samples were obtained from museum collections and/or from captive populations that stemmed from numerous individual collecting events operating over many decades. These specimens were in large part identified by their original collectors, e.g., J.B. Burch identified his extensive 1970 samples of Society Islands partulid samples in the field using Crampton's taxonomic descriptions [68]. Voucher specimen information is available in the supplemental information together with sampling details for the 662 genotyped partulid snails analyzed in this study (Additional file 3: Table S1). 


\section{Molecular data}

Total genomic DNA was isolated using the E.Z.N.A. ${ }^{\bullet}$ Mollusc DNA Kit (Omega Biotech, Norcross, GA) following the manufacturer's instructions. A 655 nucleotide fragment of the mt cytochrome oxidase I (COI) was amplified with GoTaq DNA Polymerase (Promega, Madison, WI) using the "universal" primer pairs LCO1490/HCO2198 [74]. A 805 (aligned) nucleotide fragment of the large nuclear ribosomal subunit gene (28S) was also amplified from a subset of specimens using D23F/D6R primers [75]. The amplification condition consisted of initial denaturation of $95^{\circ} \mathrm{C}$ for $2 \mathrm{~min}, 40$ cycles of denaturation $\left(95^{\circ} \mathrm{C}, 30 \mathrm{sec}\right)$, annealing $\left(45^{\circ} \mathrm{C}\right.$ for $\mathrm{COI}$ and $50^{\circ} \mathrm{C}$ for $\left.28 \mathrm{~S}, 30 \mathrm{sec}\right)$, extension $\left(72^{\circ} \mathrm{C}\right.$, $1 \mathrm{~min}$ ), and a final extension at $72^{\circ} \mathrm{C}$ for $5 \mathrm{~min}$. Amplification products were prepared for cycle sequencing by diluting 1:5 in sterile water. Sequencing was performed in both directions, using the PCR primers, at the University of Michigan DNA Sequencing Core Facility. All DNA sequences obtained have been deposited in GenBank (Additional file 3: Table S1). The resulting chromatograms were edited by comparing both strands using Sequencher 4.8 (Gene Codes Corporation, Ann Arbor, Michigan, USA) and the edited sequences were aligned by eye in Se-Al v2.0a11 [76]. In total, 667 partulids were typed for mt COI and 130 snails for the large nuclear ribosomal subunit gene (28S), yielding 312 and 89 distinct genotypes, respectively.

\section{Phylogenetic analyses}

Maximum parsimony (MP), maximum likelihood (ML) and Bayesian analyses were performed using the partulid genus Eua as the outgroup [39]. MP searches were heuristic using PAUP* 4.0b10 [77] with 100 random stepwise additions (MaxTrees set to 10,000) and tree-bisectionreconnection (TBR) branch-swapping. Bootstrap [78] branch support (BS) levels were estimated with 100 replicates (MaxTrees set to 100), 10 random additions each. ML analyses were performed using PAUP* under the bestfit model of nucleotide substitution (COI: $\mathrm{K} 81 \mathrm{uf}+\mathrm{I}+\mathrm{G}$, 28S: GTR + I + G) selected by the Akaike Information Criterion in 3.7 [79]. The neighbor-joining tree was used as the starting tree with the likelihood parameters found in Modeltest. The branch-swapping algorithm was set to nearest neighbor interchange (NNI) for COI and to TBR for $28 \mathrm{~S}$ dataset. Bootstrap support values were estimated using a fast-heuristic search with 100 replicates. Bayesian searches were run for $100 \times 10^{6}$ generations in MrBayes 3.1.2 [80] set for the GTR $+\Gamma+$ I model. Model parameters were treated as unknown and were estimated for each analysis. Four chains were run simultaneously and trees were sampled every 10,000 cycles. Posterior probability values were estimated by generating a $50 \%$ majority rule consensus tree after the burn-in period of 2,500 using PAUP*.

\section{Time-calibrated BEAST analyses}

We chose three time calibration points by identifying within our partulid mt COI Bayesian analysis the most comprehensively sampled, robustly supported clades that were restricted to specific archipelagos or islands of known age. Unsurprisingly, all three concerned Society Islands Partula species, by far our best-sampled archipelago and genus. Each calibration was chosen to represent a particular temporal reference point from the geological history of the archipelago. The oldest, Calibration point A (Figure 6), represents the inferred age of the oldest island in the archipelago bearing partulid tree snails: Bora Bora, 4.01-3.21 Mya [81]. The corresponding Eastern Partula clade (PPS = 100; Figure 5) includes genotypes from all individuals sampled in the Society Islands and from Rarotonga, which we consider to be a founder population. The next oldest, Calibration point B (Figure 6), represents the inferred age of Raiatea: 2.75-2.44 Mya [82] and the corresponding, well-supported clade (PPS = 97; Figure 5), was exclusively composed of Raiatean taxa. The youngest, Calibration point B (Figure 6), represents the inferred age of Tahiti: 1.12-0.50 Mya [82], the youngest Society Island bearing partulid tree snails. This was applied to the largest Tahiti-exclusive clade (PPS =99; Figure 5), which probably represents the oldest sampled Tahitian partulid lineage.

We used BEAST 1.7.1 [83] to estimate a time-calibrated partulid phylogeny. This involved employing an uncorrelated lognormal distribution for the molecular clock and the SRD06 Model [84] for codon positions. Normal distributions were used to characterize prior distributions of the clade ages. Two independent MCMC analyses were run for 50 million iterations respectively and sampled every 5000 iterations. Convergence diagnostics were conducted in Tracer v1.5 [85] and reliable ESS values (>200) were ensured. The first $10 \%$ trees were discarded as burnin respectively and the trees were combined in LogCombiner [83]. A maximum credibility tree was generated from the combined trees in TreeAnnotater [83].

\section{Availability of supporting data}

Museum vouchers have been deposited for genotyped snails, DNA sequences have been deposited in GenBank (see Additional file 3: Table S1 for details) and phylogenetic data have been deposited in TreeBase (reference \# 16092).

\section{Additional files}

Additional file 1: Figure S1. Bayesian phylogenetic tree showing topological details of the entire Partulidae $\mathrm{mt} \mathrm{COl}$ dataset. The taxonomic identity of each haplotype is given together with its geographic origin and (for previously published haplotypes) the GenBank reference

number. Support levels are shown for each node; from left-to-right: Maximum Parsimony bootstrap support values ( $>70)$, Maximum Likelihood bootstrap support values $(>70)$, Bayesian posterior probabilities 
(>90), respectively. Background details on the genotyped snails are presented in Additional file 3: Table S1.

Additional file 2: Figure S2. A time calibrated $\mathrm{mt}$ COI BEAST phylogeny of Partulidae showing details of the entire topology. The taxonomic identity of each haplotype is given together with its geographic origin. Date estimates are shown for each node. Within the topology, branches are color-coded for easy reference: green for species of the genus Eua, red for species of the genus Samoana, dark blue for Western Partula species and light blue for Eastern Partula species. Background details on the genotyped snails are presented in Additional file 3: Table S1.

Additional file 3: Table S1. Table showing the taxonomic designation, sampling location, shell voucher specimen catalogue number and GenBank Accession number for every partulid genotype employed in this study.

\section{Competing interests}

The authors declare that they have no competing interests.

\section{Authors' contributions}

DÓF and TL conceived and designed the study; TL generated the sequences incrementally over a 10-year period as museum, zoo and field samples became available; TL performed the Bayesian and Maximum Likelihood phylogenetic analyses; JL and CKCC performed the BEAST analyses; DÓF drafted the manuscript and oversaw figure design; All authors read and approved the final manuscript.

\section{Acknowledgements}

This work was supported by NSF awards DEB-0425984 \& OCE 0850625 to D. Ó Foighil. J. Megahan provided expert graphical assistance. Our senior colleague, J.B. Burch, generously granted us full access to his invaluable collection of 1970's era lyophilized partulid tissues. We gladly acknowledge other colleagues who kindly provided additional specimens: A. Baldinger, P. Bouchet, T. Coote, B. Fontaine, O. Gargominy, J. Gerber, C. Hickman, B. Holland, R. Kawamoto, F. Kraus, J-Y Meyer, P. Pearce-Kelly and R. Rundell. Our thanks to the mollusk collections of the Field Museum, Bishop Museum, Carnegie Museum and Museum of Comparative Zoology for providing reference material on loan. The manuscript was improved by the critical comments of three anonymous reviewers.

\section{Author details}

'Museum of Zoology and Department of Ecology and Evolutionary Biology, University of Michigan, 1109 Geddes Avenue, Ann Arbor, Ml 48109-1079, USA. ${ }^{2}$ Present Address: Marine Science Institute, University of California, Santa Barbara, Santa Barbara, CA 93106-6150, USA.

Received: 16 December 2013 Accepted: 16 September 2014 Published online: 24 September 2014

\section{References}

1. Steadman DW: Extinction \& Biogeography of Tropical Pacific Birds. Chicago: University of Chicago Press; 2006.

2. Paulay G, Meyer C: Diversification in the tropical Pacific: comparisons between marine and terrestrial systems and the importance of founder speciation. Integr Comp Biol 2002, 42:922-934.

3. Paulay G: Biodiversity on oceanic islands - its origin and extinction. Am Zool 1994, 34:134-144.

4. Wagner WL, Funk VJ: Hawaiian Biogeography. Evolution on a Hot Spot Archipelago. Washington DC: Smithsonian Institution Press; 1995.

5. Cowie RH, Holland BS: Dispersal is fundamental to biogeography and the evolution of biodiversity on oceanic islands. J Biogeogr 2006, 33:193-198.

6. Haney L: Is a new paradigm emerging for oceanic island biogeography? J Biogeogr 2007, 34:753-757.

7. Carlquist S: Island Biology. New York: Columbia University Press; 1974.

8. Vermeij GJ: Inequality and the directionality of history. Am Nat 1999, 153:243-253.

9. Gillespie RG, Roderick GK: Arthropods on islands: evolution and conservation. Ann Rev Entomol 2002, 47:595-632.

10. Cronk QCB: Islands: stability, diversity, conservation. Biodiversity Conserv 1997, 6:477-493.
11. Woinarski JCZ: Biodiversity conservation in tropical forest landscapes of Oceania. Biol Cons 2010, 143:2385-2394.

12. Pimm SL: The Balance of Nature?. Chicago: University of Chicago Press; 1991.

13. Cowie RH: Pacific Island Land Snails: Relationships, Origins and Determinants of Diversity. In The Origin and Evolution of Pacific Island Biotas, New Guinea to Eastern Polynesia: Patterns and Processes. Edited by Keast A, Miller SE. Amsterdam: SPB Publishing; 1996:347-372.

14. Wiles GJ, Bart J, Beck RE, Aguon CF: Impacts of the brown tree snake: patterns of decline and species persistence in Guam's avifauna. Conserv Biol 2003, 17:1350-1360.

15. Vitousek PM: Diversity and Biological Invasions of Oceanic Islands. In Biodiversity. Edited by Wilson EO. Washington: National Academy Press; 1988:181-189.

16. Sax DF, Gaines SD: Species invasions and extinction: the future of native biodiversity on islands. Proc Natl Acad Sci U S A 2008, 105:11490-11497.

17. Régnier $C$, Fontaine $B$, Bouchet $P$ : Not knowing, not recording, not listing: numerous unnoticed mollusk extinctions. Conserv Biol 2009, 23:1214-1221

18. Hadfield MG, Miller SE, Carwile AH: The decimation of endemic Hawai'ian tree snails by alien predators. Am Zool 1993, 33:610-622.

19. Civeyrel $L$, Simberloff $D$ : $A$ tale of two snails: is the cure worse than the disease? Biodiversity Conserv 1996, 5:1231-1252.

20. Cowie RH: Non-Indigenous Land and Freshwater Molluscs in the Islands of the Pacific: Conservation Impacts and Threats. In Invasive Species in the Pacific: A Technical Review and Regional Strategy. Edited by Sherley G. Samoa: South Pacific Regional Environment Programme; 2000:143-172.

21. Lydeard C, Cowie RH, Ponder WF, Bouchet P, Clark SA, Cummings KS, Frest TJ, Gargominy O, Herbert DG, Hershler R, Perez KE, Roth B, Seddon M, Strong EE, Thompson FG: The global decline of nonmarine mollusks. Bioscience 2004, 54:321-330.

22. Clarke B, Murray J, Johnson MS: The extinction of endemic species by a program of biological control. Pac Sci 1984, 38:97-104.

23. Cowie RH: Evolution and extinction of Partulidae, endemic Pacific island snails. Philos Trans R Soc London B 1992, 335:167-191.

24. Hopper DR, Smith BD: Status of tree snails (Gastropoda: Partulidae) on Guam, with a resurvey of sites studied by H.E. Crampton in 1920. Pac Sci 1992, 46:77-85.

25. Cowie RH, Cook RP: Extinction or survival: partulid tree snails in American Samoa. Biodiversity Conserv 2001, 10:143-159.

26. Coote T, Loève E: From 61 species to five: endemic tree snails of the Society Islands fall prey to an ill-judged biological control programme. Oryx 2003, 37:91-96.

27. Clench WJ: A new subspecies of Paupina with records of land mollusks from Eastern Papua and associated islands. The Nautilus 1936, 50:53-54.

28. Ó Foighil D, Lee T, Slapcinsky J: Prehistoric anthropogenic introduction of partulid tree snails in Papua New Guinean archipelagoes. J Biogeography 2011, 38:1625-1632.

29. Vagvolgyi J: Body size, aerial dispersal, and origin of the Pacific land snail fauna. Syst Zool 1975, 24:465-488.

30. Kirchner C, Kratzner R, Welter-Schultes FW: Flying snails - how far can Truncatellina (Pulmonata: Vertiginidae) be blown over the sea? J Moll Stud 1997, 63:479-487

31. Wada S, Kawakami K, Chiba S: Snails can survive passage through a bird's digestive system. J Biogeogr 2012, 39:69-73.

32. Pilsbry HA: Manual of Conchology, Structural and Systematic. Vol. 20, Caecilioides, Glessula and Partulidae. Philadelphia, PA: Academy of Natural Sciences of Philadelphia: Conchological Department; 1909-1910:1-336.

33. Kondo Y: Partulidae: preview of anatomical revision. Nautilus 1968, 81:73-77.

34. Lee T, Burch JB, Coote T, Fontaine B, Gargominy O, Pearce-Kelly P, Ó Foighil $D$ : Prehistoric inter-archipelago trading of Polynesian tree snails leaves a conservation legacy. Proc R Soc Lond B 2007, 272:2907-2914.

35. Lee T, Burch JB, Coote T, Pearce-Kelly P, Hickman C, Meyer J-Y, Ó Foighil D: Moorean tree snail survival revisited: a multi-island genealogical perspective. BMC Evol Biol 2009, 9:204.

36. Emerson BC: Evolution on oceanic islands: molecular phylogenetic approaches to understanding pattern and process. Mol Ecol 2002, 11:951-966.

37. Sato A, Tichy H, O'hUigin C, Grant PR, Klein J: On the origin of Darwin's finches. Mol Biol Evol 2001, 18:299-311.

38. Baldwin BG, Sanderson MJ: Age and rate of diversification of the Hawaiian silversword alliance. Proc Natl Acad Sci U S A 1998, 95:9402-9406. 
39. Wade CM, Mordan PB, Naggs F: Evolutionary relationships among the Pulmonate land snails and slugs (Pulmonata, Stylommatophora). Biol J Linn Soc 2006, 87:593-610.

40. Tillier S, Mordan PB: The anatomy and systematics of the New Caledonian land snail genus Draparnaudia Montrouzier, 1859 (Pulmonata: Orthurethra). Zool J Linn Soc 1995, 113:47-91.

41. Bouchet $P$, Rocroi JP, Frýda J, Hausdorf B, Ponder W, Valdés Á, Warén A: Classification and nomenclator of gastropod families. Malacologia 2005, 47:1-397.

42. Pilsbry HA, Cooke CM: Partulidae of Tonga and related forms. Bernice $P$ Bishop Mus Occas Papers 1934, 10:3-22.

43. Johnson MS, Murray J, Clarke B: An electrophoretic analysis of phylogeny and evolutionary rates in the genus Partula from the Society Islands. Proc R Soc Lond B 1986, 227:161-177.

44. Goodacre SL, Wade CM: Molecular evolutionary relationships between partulid land snails of the Pacific. Proc R Soc Lond B 2001, 268:1-7.

45. Lee T, Meyer JY, Burch JB, Pearce-Kelly P, Ó Foighil D: Not completely gone: two partulid tree snail species persist on the highest peak of Raiatea, French Polynesia. Oryx 2008, 42:615-619.

46. Johnson MS, Murray J, Clarke B: Evolutionary relationships and extreme genital variation in a closely related group of Partula. Malacologia 1993, 35:43-61.

47. Burch JB: A new species of land snail (Stylommatophora: Partulidae) from Raiatea, French Polynesia, Oceania. Occas Pap Mus Zool Univ Mich 2007, 740:8.

48. Kondo Y, Burch JB: Archaic land snails of the Pacific islands. Malac Rev 1972, 5:17-18.

49. Johnson MS, Murray J, Clarke B: The ecological genetics and adaptive radiation of Partula on Moorea. Oxford Surv Evolut Biol 1993, 9:167-236.

50. Murray J, Stine OC, Johnson MS: The evolution of mitochondrial DNA in Partula. Heredity 1991, 66:93-104

51. Goodacre SL, Wade CM: Patterns of genetic variation in Pacific island land snails: the distribution of cytochrome $b$ lineages among Society Island Partula. Bio J Linn Soc 2001, 73:131-138.

52. Goodacre SL: Population structure, history and gene flow in a group of closely related land snails: genetic variation in Partula from the Society Islands of the Pacific. Mol Ecol 2002, 11:55-68.

53. Gillespie RG, Claridge EM, Goodacre SL: Biogeography of the fauna of French Polynesia: diversification within and between a series of hot spot archipelagos. Philos Trans R Soc Lond B 2008, 363:3335-3346.

54. Kondo Y: Samoana of the Society Islands (Pulmonata: Partulidae). Malac Rev 1973, 6:19-33.

55. Johnson MS, Murray J, Clarke B: High genetic similarities and low heterozygosities in land snails of the genus Samoana from the Society Islands. Malacologia 1986, 27:97-106.

56. Kondo Y: A Revision of the Family Partulidae. Cambridge, MA: PhD thesis Harvard University, Department of Biology; 1955.

57. Johnson MS, Murray J, Clarke B: Parallel evolution in Marquesan partulid land snails. Bio J Linn Soc 2000, 69:577-598.

58. Meyer JY, Jourdan H, Malau A: Recent incursions of invasive animal and plant species in the small and remote archipelago of Wallis and Futuna (South Pacific): "La Maison Brûle mais nous regardons ailleurs". Aliens 2008, 27:8-9.

59. Rundell RJ: Diversity and conservation of the land snail fauna of the western Pacific islands of Belau (Republic of Palau, Oceania). Am Malacol Bull 2010, 28:81-90.

60. Fontaine B, Gargominy O, Prié V: Indigenous Land Snails. In The Natural History of Santo, \# 70. Edited by Bouchet P, Le Guyader H, Pascal O. Paris: Museum National d'Historie Naturelle, Patrimoines Naturels; 2011:169-179.

61. Pelep PO, Hadfield MG: The status of the endemic snails of the genus Partula (Gastropoda: Partulidae) on Pohnpei, Federated States of Micronesia. Micronesica 2011, 41:253-262.

62. Cooke CM, Crampton HE: New species of Partula. B P Bishop Mus Occ Papers 1930, 9:3-5.

63. Murray J, Clarke B: The genus Partula on Moorea: speciation in progress. Proc R Soc Lond B 1980, 211:83-117.

64. Clarke B, Johnson MS, Murray J: Clines in the genetic distance between two species of island land snails: how "molecular leakage" can mislead us about speciation. Philos Trans R Soc Lond B 1996, 351:773-784.

65. Hickman CS: Origination, Evolutionary Radiation, and Extinction in the Modern World: The Story of Partulid Tree Snails. In Evolution: Investigating the Evidence, 9. Edited by Scotchmoor J, Springer DA. Pittsburgh, PA: Paleontological Society Special Publication; 1999:261-280.
66. Duncan RA, McDougall I: Linear volcanism in French Polynesia. J Volcanol Geotherm Res 1976, 1:197-227.

67. Hildenbrand A, Gillot PY, Le Roy I: Volcano-tectonic and geochemical evolution of an oceanic intra-plate volcano: Tahiti-Nui (French Polynesia). Earth Planet. Sci Lett 2004, 217:349-365

68. Lee $T$, Burch JB, Jung $Y$, Coote T, Pearce-Kelly $P$, Ó Foighil D: Tahitian tree snail mitochondrial clades survived recent mass-extirpation. Curr Biol 2007, 17:R502-R503.

69. Meyer JY: Threat of invasive alien plants to native flora and forest of Eastern Polynesia. Pac Sci 2004, 58:357-375.

70. Gillespie RG, Claridge EM, Roderick GK: Biodiversity dynamics in isolated island communities: interaction between natural and human-mediated processes. Mol Ecol 2008, 17:45-57.

71. Allison A: Zoogeography of Amphibians and Reptiles of New Guinea and the Pacific Region. In The Origin and Evolution of Pacific Island Biotas, New Guinea to Eastern Polynesia: Patterns and Processes. Edited by Keast A, Miller SE. Amsterdam: SPB Academic Publishing; 1996:407-436.

72. Flannery TF: Mammalian Zoogeography of New Guinea and the Southwestern Pacific. In The Origin and Evolution of Pacific Island Biotas, New Guinea to Eastern Polynesia: Patterns and Processes. Edited by Keast A, Miller SE. Amsterdam: SPB Academic Publishing; 1996:399-406.

73. Ó Foighil D: Conservation status update on Society Island Partulidae. Tentacle 2009, 17:30-35.

74. Folmer O, Black M, Hoeh W, Lutz R, Vrijenhork R: DNA primers for amplification of mitochondrial cytochrome c oxidase subunit I from diverse metazoan invertebrates. Mol Mar Biol Biotech 1994, 3:294-299.

75. Park JK, Ó Foighil D: Sphaeriid and corbiculid clams represent separate heterodont bivalve radiations into freshwater environments. Mol Phylogenet Evol 2000, 14:75-88.

76. Rambaut A: SE-AL Sequence Alignment Editor, v2.0a11. Oxford: University of Oxford; 2002. http://tree.bio.ed.ac.uk/software/seal/.

77. Swofford DL: PAUP*: Phylogenetic Analysis Using Parsimony ( ${ }^{*}$ and Other Methods). In Version 4. Sunderland, MA: Sinauer Associates; 2003.

78. Felsenstein J: Confidence limits on phylogenies: an approach using the bootstrap. Evolution 1985, 39:783-791.

79. Posada D, Crandall KA: MODELTEST: testing the model of DNA substitution. Bioinformatics 1998, 14:817-818.

80. Ronquist F, Huelsenbeck JP: MrBayes 3: Bayesian phylogenetic inference under mixed models. Bioinformatics 2003, 19:1572-1574.

81. Uto K, Yamamoto Y, Sudo M, Uchiumi S, Ishizuka O, Kogiso T, Tsunakawa H: New K-Ar ages of the Society Islands, French Polynesia, and implications for the Society hotspot feature. Earth Planets Space 2007, 59:879-885.

82. Guillou H, Maury RC, Blais S, Cotton J, Legendre C, Guille G, Caroff M: Age progression along the Society hotspot chain (French Polynesia) based on new unspiked K-Ar ages. Bull Soc Geol Fr 2005, 176:135-150.

83. Drummond AJ, Suchard MA, Xie D, Rambaut A: Bayesian phylogenetics with BEAUti and the BEAST 1.7. Mol Biol Evol 2012, 29:1969-1973.

84. Shapiro B, Rambaut A, Drummond AJ: Choosing appropriate substitution models for the phylogenetic analysis of protein-coding sequences. Mol Biol Evol 2006, 23:7-9.

85. Rambaut A, Drummond AJ: Tracer v. 1.5. Oxford: University of Oxford; 2009 www.who.int/growthref.

doi:10.1186/s12862-014-0202-3

Cite this article as: Lee et al:: Evolutionary history of a vanishing

radiation: isolation-dependent persistence and diversification in Pacific Island partulid tree snails. BMC Evolutionary Biology 2014 14:202. 